\title{
Diversifikasi Pangan Melalui Pemanfaatan Sumberdaya Lokal"Uwi" Sebagai Bahan Mie Instant
}

\author{
Wuryantoro ${ }^{1}$, Indah Rekyani Puspitawati ${ }^{2}$ \\ ${ }^{1}$ Dosen Fakultas Pertanian, Universitas Merdeka Madiun, Jl. Serayu No. 79, Madiun, 63133 \\ E-mail: wuryantoro@unmer-madiun.ac.id \\ ${ }^{2}$ Dosen Fakultas Pertanian, Universitas Merdeka Madiun, Jl. Serayu No. 79, Madiun, 63133 \\ E-mail: indahrekyani@unmer-madiun.ac.id
}

\begin{abstract}
Uwi plants (Dioscorea sp.) as one of the types of tuber plants have the potential to support food diversity and food security in the future because it is very tolerant to be planted on dry land with a huge potential in Indonesia. The research aims to obtain a variety of diversified foods based on uwi plants. The research method used a completely randomized design laboratory scale consisting of six treatments repeated three times. These factors are the various colors of tubers used as research material including dark yellow (orange), yellow, murky white, white, purple and purple spurt. Observations include texture, elasticity, aroma, colour and taste through organoleptic tests. Instant noodles and wet noodles are used as a comparison. The study was conducted in the Agronomy Laboratory of the Faculty of Agriculture, Merdeka University, Madiun, from October to December 2018. The results showed that compared to conventional noodles as a control, the appearance of colour, taste, texture and aroma of noodles after being cooked was not much different. Whereas seen from the elasticity of uwi noodles has a lower elasticity. The difference is also in the appearance of raw dried noodles, the color and aroma are still inferior to dry noodles and instant noodles. Thus, uwi flour is potential to be developed as a food ingredient, considering that uwi carbohydrates have a low glycemic index.
\end{abstract}

Keywords —: food diversity; dry noodle; tuber color; uwi flour.

\section{PENDAHULUAN}

Masalah serius dihadapi Indonesia berkaitan komoditi pangan utama adalah ketergantungan yang sangat tinggi terhadap beras, sehingga sering terjadi kelangkaan. Kelangkaan ini sebenarnya dulu tidak terjadi karena tidak semua daerah di Indonesia mengonsumsi beras dan tetap bertahan dengan makanan utama masing-masing sehingga impor bahan makanan pokok beras bisa ditiadakan atau minimal dikurangi (Akbar Anwari, 2014). Dampak yang muncul adalah adanya lonjakan konsumsi/kebutuhan beras nasional sehingga memaksa pemerintah untuk impor beras.Indonesia sebagai negara kepulauan yang memiliki beragam ekosistem sangat cocok bila bahan pangan pokok penduduknya beranekaragam. Penyediaan bahan pangan sesuai potensi daerah masing-masing akan sangat memudahkan masyarakat karena masyarakat dapat mencukupi kebutuhan pangan dengan apa yang tersedia di daerahnya (Hubeis, 2012 dalam Arif Dwi Santoso, 2013).Selain itu, produksi beras, selalu identik dengan pertanian berbasis sawah/irigasi, dan ketergantungan terhadap beras menyebabkan terjadinya eksploitasi terhadap lahan irigasi sehingga dengan cepat mengalami deteriorasi.Kondisi demikian menyebabkan semakin pentingnya peran lahan kering (non irigasi) sebagai penopang produk pangan khususnya diversifikasi ke non beras. Kenyataan menunjukkan bahwa sekitar 40\% lahan pertanian dunia adalah lahan kering yang terdistribusikan di Asia (34,4\%), Afrika (24,15\%) dan Amerika 24,03 \%. Di Indonesia sendiri potensi lahan kering sekitar 66,47 juta hektar menempati porsi sekitar 50\% lahan Indonesia (Faisal K. dan Haryono, S, 2012). Lahan ini merupakan lahan potensial penunjang ketahanan pangan apabila dikelola dengan baik, serta system budidaya yang memadai.

Tanaman uwi merupakan sumber karbohidrat yang sangat potensial untuk diversifikasi pangan, mengingat tanaman ini sangat toleran ditanam di lahan kering dengan daya produksi yang tinggi. Dengan adanya kebijakan pola makan berbasis beras, keberadaan tanaman uwi mulai tersingkir dan semakin langkadan dikawatirkan sumber genetik tanaman uwi akan semakin hilang, padahal sumber genetik (plasma nutfah) merupakan karunia Tuhan yang tak ternilai harganya dan akan sangat bermanfaat bagi pengembangan pertanian di masa datang. Oleh karena itu upaya pelestarian plasma nutfah tanaman uwi dan juga tanaman sumber karbohidrat lain mempunyai nilai strategis bagi keberhasilan ketahanan pangan di masa mendatang saat jumlah penduduk terus meningkat yang kontradiktif dengan semakin menurunnya kuantitas dan kualitas lahan pertanian. Beras yang telah mendominasi di masyarakat, seakan-akan menutup peluang pengembangan komoditas lain seperti halnya tanaman uwi yang potensi produktivitasnya di Indonesia sangat besar. Tanaman non padi ini dapat diolah menjadi tepung yang dapat digunakan menjadi bahan beras beras sintetis. Permasalahan lain dihadapi saat budidaya uwi secara komersial adalah keterbatasan bibit yang selama ini hanya menggunakan bagian pucuk dari umbi, sehingga ketersediaan bibit sangat terbatas. Umbi uwi yang hakekatnya adalah umbi batang mempunyai banyak tunas, sehingga diharapkan dari limbah dan sisa umbi konsumsi dapat digunakan untuk perbanyakan tanaman.

Tanaman uwi (Dioscorea sp) adalah salah satu tanaman sumber karbohidrat yang sangat potensial dengan alasan :

1. Tanaman ini sangat cocok untuk ditanam di lahan kering yang luasnya mencapai $50 \%$ lahan pertanian di Indonesia

2. Tanaman ini telah menjadi tanaman pangan penting di wilayah Papua (Irian Jaya) (Sukar, 1996) 
Website : http://agritek.unmermadiun.ac.id/index.php/agritek

3. Tanaman uwi (Yam) juga merupakan bahan makanan penting di beberapa Negara Afrika khususnya Nigeria ( Tobin F. O., 2011)

4. Kandungan karbohidrat uwi mencapai $72,6-80,2 \%$ dari berat keringnya,

5. Produktivitas uwi cukup tinggi dapat mencapai 70 ton per hektar (Kay, 1987 dalam Sukar 1996).

6. Uwi merupakan tanaman semusim, dengan teknis budidaya yang cukup mudah, tidak memerlukan teknologi tinggi.

7. Tanaman uwi merupakan tanaman merambat yang dapat diintegrasikan dengan tanaman keras atau berbentuk agroforestry.

8. Kelestarian tanaman uwi cukup memprihatinkan sehingga perlu segera ada penanganan serius.

Dari berbagai alasan tersebut, maka upaya eksplorasi, pelestarian, dan pengembangan tanaman uwi sebagai salah satu sumber pangan masa depan melalui diversifikasi pangan mutlak harus segera dilakukan. Teknis pembuatan mie instan berbasis tanaman uwi merupakan salah satu upaya memperoleh bahan pangan alternatif serta pangan fungsional. Hasil penelitian Regina et al, 2011 menunjukkan bahwa di Nigeria produksi dan konsumsi uwi terus meningkat dari tahun 1996 hingga 2006 dengan peningkatan relatiflebih dari $400 \%$, yang menunjukkan potensi uwi sebagai bahan pangan masa depan semakin penting. Sedangkan untuk memperoleh produksi tinggi, penanaman di awal musim sangat dianjurkan (Tobih et, al, 2011). Indonesia sebagai negara kepulauan yang memiliki beragam ekosistem sangat cocokbila bahan pangan pokok penduduknyaberanekaragam. Penyediaan bahan pangansesuai potensi daerah masing-masing akansangat memudahkan masyarakat karenamasyarakat dapat mencukupi kebutuhanpangan dengan apa yang tersedia didaerahnya (Hubeis, 2012 dalam Arif Dwi Santoso, 2013). Perhatianterhadap pengembangan komoditas sumberkarbohidrat selain beras masih sangat kurang,padahal bahan pangan sumber karbohidratlokal sebagai pendamping beras beragamjumlahnya. Beras yang telah mendominasi dimasyarakat, seakan-akan menutup peluangpengembangan komoditas lain. Hasil penelitian Wuryantoro et al (2016) menunjukkan bahwa di wilayah tertentu tanaman uwi sudah mulai langka di masyarakat. Hasil eksplorasi di 5 kabupaten se eks Karesidenan Madiun diperoleh 127 asesi uwi yang terdiri dari Dioscorea alata, Dioscorea hispida, Dioscorea aculeata, Dioscorea bulbifera dan Dioscorea pentaphyla. Hasil penelitian Purba H.F (2014) menunjukkan bahwa secara financial usaha pengolahan mie basah tepung komposit ubi jalar putih dengan tepung terigu memberikan keuntungan relatif tinggi dibandingkan dengan usaha pengolahan tepung terigu $100 \%$, ditunjukkan oleh nilai B/C pengolahan mie basah komposit ubi jalar dengan tepung terigu lebih tinggi dari B/C pengolahan mie basah $100 \%$ tepung terigu. Dengan penelitian ini sangat memungkinkan dibuatnya mie basah dari bahan uwi dengan keunggulan mempunyai indeks glikemik rendah.

\section{METODE PENELITIAN}

\section{A. Tempat dan Waktu}

Penelitian akan dilaksanakan di laboratorium dan kebun percobaan Fakultas Pertanian Universitas Merdeka Madiun. Pelaksanaan percobaan pada bulan Oktober sampai dengan Nopember 2018.

\section{B. Bahan dan alat}

Bahan yang diperlukan meliputi umbi 6 jenis Uwi spesies Dioscorea alata bahan additif maizena dan tepung tapioka. Asam sitrat, garam dan $\mathrm{CaCO} 3$ digunakan untuk perendaman bahan umbi segar untuk menghilangkan lender. Alat yang diperlukan meliputi bak media perendaman, peralatan masak, oven, alat giling dan peralatan uji organoleptik.

\section{Metode Penelitian}

Penelitian menggunakan Rancangan Acak Lengkap diulang tiga kali.

\begin{tabular}{|c|c|}
\hline Kode & Keterangan \\
\hline U1 & $\begin{array}{l}\text { Mie dibuat dari bahan tepung umbi uwi warna kuning tua } \\
\text { /orange }\end{array}$ \\
\hline $\mathrm{U} 2$ & Miedibuat dari bahan tepung umbi uwi warna kuning \\
\hline U3 & Mie dibuat dari bahan tepung umbi uwi warna putih keruh \\
\hline $\mathrm{U} 4$ & Mie dibuat dari bahan tepung umbi uwi warna putih \\
\hline U5 & Mie dibuat dari bahan tepung umbi uwi warna ungu \\
\hline U6 & $\begin{array}{l}\text { Mie dibuat dari bahan tepung umbi uwi warna ungu } \\
\text { sembur }\end{array}$ \\
\hline U7 & Mie kering \\
\hline U8 & Sebagai kontrol \\
\hline U9 & Mie basah \\
\hline
\end{tabular}



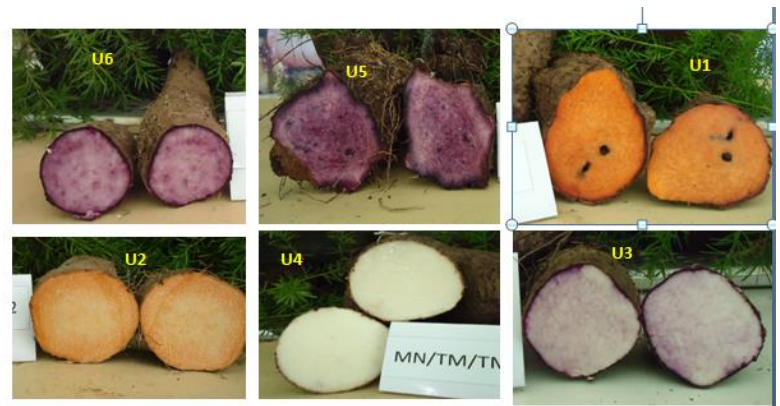

Gambar 1. Bahan Penelitian

\section{Pelaksanaan Penelitian}

Pelaksanaan penelitian meliputi persiapan bahan/tepung, pembuatan mie, pengolahan mie dan uji organoleptik.

Bahan dipersiapkan dari koleksi hasil penelitian sebelumnya (Wuryantoro, 2016) dipilih 6 asesi sesuai kebutuhan penelitian. Persiapan meliputi pembuatan chips, perendaman, pengeringan dan penggilingan hingga menjadi tepung uwi halus. Pembuatan mie, meliputi pencampuran bahan (tepung uwi, tepung terigu dan tapioka) dengan perbandingan 50:30:20 ditambah 1 sendok makan STPP (Sodium Tri Poly Phosfat) pada setiap $350 \mathrm{ml}$ air campuran. Campuran kemudian dicetak untuk membentuk untaian mie basah, kemudian dikukus 15 menit dan dikeringkan untuk mendapatkan mie kering. Untuk uji organoleptik mie diolah dengan resep bumbu yang sama, berikut mie basah terigu, mie kering dan mie instan sebagai control/pembanding. Pengamatan dalam uji organoleptik meliputi tampilan warna, kekenyalan, tekstur dan rasa. Hasil pengamatan dianalisis diskriptip untuk melihat perbedaan satu dengan lainnya.

\section{III.HASIL DAN PEMBAHASAN}

\section{A. Penampian fisik dan warna}
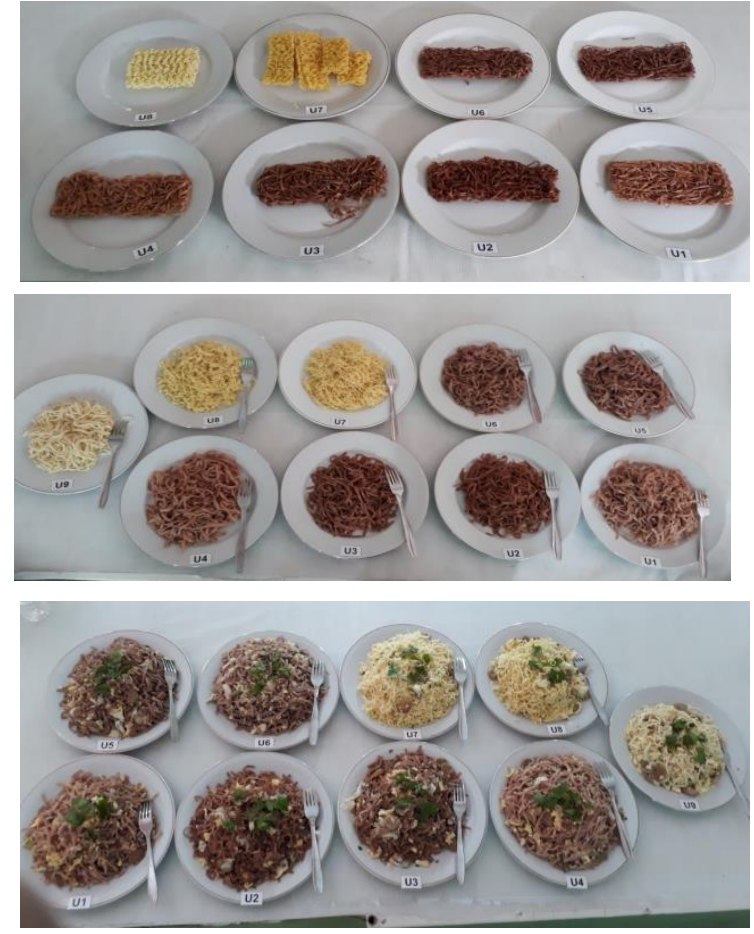

Gambar 2. Tampilan fisik olahan mie Uwi mentah (atas), basah (tengah), setelah dimasak (bawah) 
Website : http://agritek.unmermadiun.ac.id/index.php/agritek

Hasil pengujian organoleptik terhadap tampian warna olahan disajikan pada gambar di bawah ini.

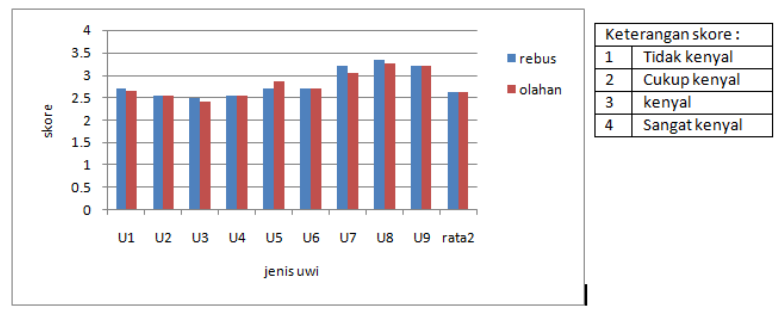

Gambar 2. Hasil pengujian tampian warna berbagai jenis olahan mie uwi

Dari gambar di atas terlihat bahwa saat belum diolah (mentah), mie kering dari uwi warna putih (U4) mempunyai tampilan warna cukup menarik dibanding lainnya, bahkan tidak jauh berbeda dengan tampilan warna mie konvensional. Sedangkan setelah dioah, mie dari uwi kuning tua mempunyai tampian warna paling baik,bahkan lebih baik dari mie konvensional.

\section{B. Rasa}

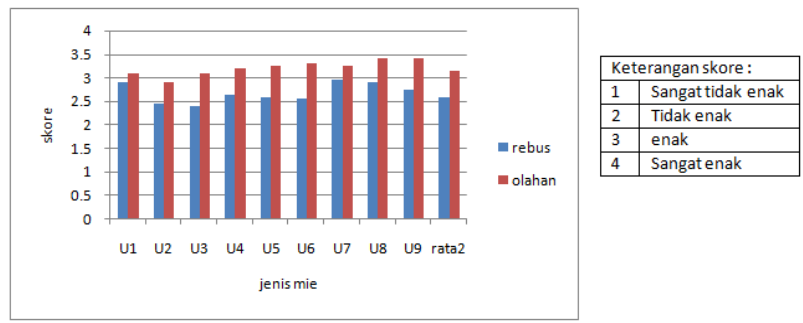

Gambar 3. Hasi pengujian rasa berbagai jenis olahan mie uwi

Terlihat bahwa dari aspek rasa, uwi rebus kalah dengan uwi konvensional, namun uwi kuning menghasilkan rasa lebih baik. Sedangkan setelah diolah, mie dari uwi mampu bersaing dengan mie konvensional, berada pada kisaran rasa cukup enak

\section{Tekstur}

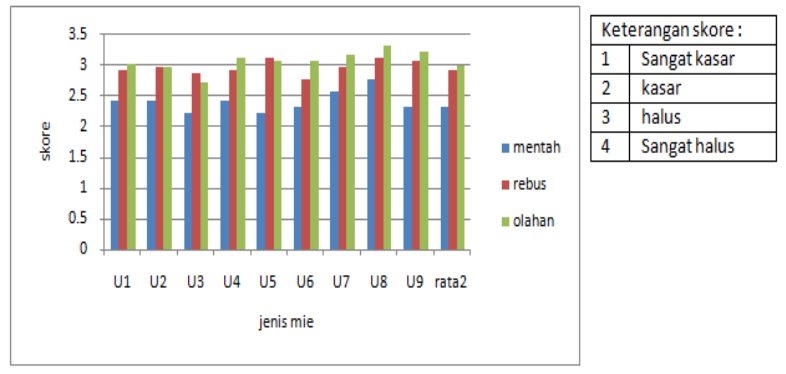

Gambar 4. Hasi pengujian Tekstur berbagai jenis olahan uwi

Saat masih mentah, rebus maupun setelah diolah tekstur tidak jauh berbeda satu sama lain dan mampu bersaing dengan mie konvensional. Tektur berada pada kisaran 3 yang berarti cukup halus.

\section{Aroma}

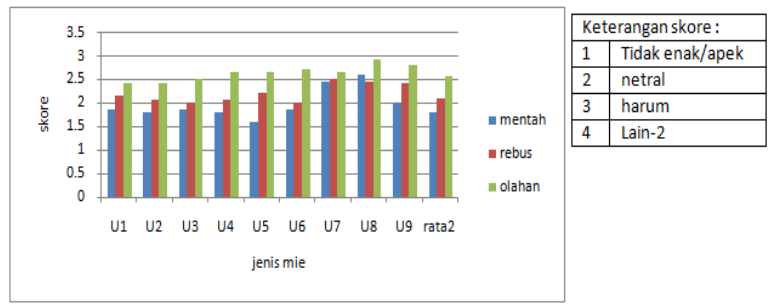

Gambar 5. Hasi pengujian aroma berbagai jenis olahan uwi

Dari segi aroma, secara umum kalah dengan mie konvensional, terutama saat masih mentah. Namun demikian saat sudah diolah aroma kurang sedap menjadi hilang dan menghasilkan bau yang netral-harum 
Website : http://agritek.unmermadiun.ac.id/index.php/agritek

Tanaman uwi merupakan sumberdaya karunia Tuhan dengan potensi yang luar biasa yang selama ini terabaikan. Pola konsumsi manusia yang sudah mainded dan identik dengan padi/beras dan terigu berikut segala jenis ragam olahannya telah menjadikan tanaman non beras terabaikan, tersingkirkan, bahkan beberapa mendekati kelangkaan dan kepunahan. Demikian halnya tanaman uwi sudah jarang ditemukan di lading-ladang masyarakat kecuali yang masih tumbuh di alam liar. Kondisi ini tentunya sangat mengkhawatirkan karena kita tidak tahu bagaimana ketersediaan dan kebutuhan pangan, pakan dan energy di masa depan. Karenanya penelitian pendayagunaan sumberdaya pangan non beras ini mutlak diperlukan untuk paling tidak sebagai upaya pelestarian plasma nutfah (Wuryantoro, 2017). Selain itu penelitian terkini semakin menunjukkan bahwa sumber karbohidrat dari umbi umbian terbukti lebih fungsional bagi kesehatan dibanding beras dan terigu.

Penelitian penggunaan umbi dan tepung tanaman umbi-umbian untuk aneka olahan sudah banyak dilakukan, namun masih sangat jarang untuk tanaman uwi. Penelitian penulis sebelumnya, terbukti bahwa tepung dari umbi uwi fungsional untuk berbagai olahan yang salah satunya adalah beras analog/fungsional (Wuryantoro et al., 2018). Selain itu hasil penelitian menunjukkan bahwa tepung umbi uwi potensial sebagai bahan pembuatan produk olahan berupa mie kering fungsional. Hasil pengujian menunjukkan bahwa secara umum olahan mie dari umbi uwi tidak jauh berbeda dalam hal warna, aroma, rasa, tekstur dan kekenyalan dibanding mie konvensional berbasis terigu (mie instan, mie basah dan mie kering). Keragaman tanaman uwi sangat besar sehingga memungkinkan dihasilkannya berbagai olahan mie dengan aneka rasa, tampilan warna serta sifat fisik lainnya. Namun ternyata dengan olahan berbasis tepung uwi, keragaman jenis uwi tidak memberikan pengaruh perbedaan nyata pada olahan yang dihasilkan. Perbedaan agak nyata ada pada aroma saat masih mentah dimana olahan uwi khususnya berbasis warna gelap memberikan aroma kurang baik (apek), namun aroma ini hilang saat menjadi olahan. Selain itu juga dalam hal kekenyalan, antara jenis uwi satu dengan lainnya tidak menunjukkan perbedaan yang nyata, namun masih kalah dengan mie konvensional berbasis terigu. Hal demikian wajar karena mie dari tepung uwi ini diolah tanpa menggunakan bahan kimia apapun sehingga menjadi lebih sehat.

\section{IV.KESIMPULAN DAN SARAN}

\section{A. Kesimpulan}

Dari pengujian organoleptik mie asal tepung uwi dapat disimpulkan bahwa :

1. Dari segi tampilan warna, tekstur dan rasa mie asal tepung uwi tidak jauh berbeda dengan mie konvensional.

2. Perbedaan terdapat pada aroma saat masih mentah dan kekenyalan yang lebih rendah dibanding mie konvensional.

3. Tepung uwi potensial untuk dibuat mie sebagai ragam pangan fungsional masa depan, mengingat potensi pengembangan tanaman uwi sangat besar.

\section{B. B. Saran}

Diperlukan penelitian lebih lanjut, terhadap aneka olahan uwi terkait aspek kualitas dan nilai gizi, dalam fungsinya sebagai pangan fungsional.

\section{DAFTAR PUSTAKA}

Agbarevo, M.N. Benjamin, 2014. An Evaluation Of Farmer's Adoption Of Yam Mini-Sett Technique In Cross-River State, Nigeria. European Of Research in Social State, Vol. 2 No. 3. Departmen Of Rural Sociology and Extension, Michael Okpara University Of Agricultura, Umudike, Nigeria.

Akbar Anwari, 2014. Kondisi Ketahanan Pangan Indonesia Saat Ini. Kompasiana Agrobis. www. kompasiana.akbar anwari. unduh 18 Mei 2015.

Anonim, 2013. Uwi-uwian (Dioscorea) : Pangan Alternatif yang belum Banyak Dieksplotasi. Balai Penelitian Tanaman Aneka Kacang dan Umbi.http ://balitkabi.litbang pertanian.go.id.

Anonim, 2014. Ketahanan Pangan dan Kedaulatan Pangan : Semua Pihak terlibat. Portal Nasional RI.Kementerian Sekretariat Negara Republik Indonesia.

Dian Indra Sari, S.P. ?.Pentingnya Plasma Nutfah dan Upaya Pelestariannya. Pengawas Benih Tanaman Ahli Pertama. BBPPTP. Surabaya

Dwi Susanto, 2010. Pertumbuhan Umbi Dioscorea alata Pada Perlakuan Pemberian bahan Organik dan Pupuk NPK. Mulawarman Scientific, Volume 9, Nomor 1. FMIPA Universitas Mulawarman.

Ironkwe, A. G., and R Asiedu, 2014. Women Farmers in Seed Yam Production : Implication For increased productivity and Sustainable Yam Improvement in Southeasthern Nigeria. A Research Article in AJRTC (2014) African Journal of Root and Tuber Crops Vol. 11 No. 1.56-64.

Lingga, P, B. Sarwono, F. Rahardi, P.C. Rahardja, J.J. Afriastini, R. Wudianto, W.H. Apriadji, 1992. Bertanam Ubi-ubian. Penebar Swadaya. Jakarta.

Purba H.F., N.D.M.Romauli Hutabarat dan B Napitupulu, 2014. Kajian Pembuatan Mie Basah Dari Tepung Ubi Jalar Putih Di Sumatera Utara. Prosiding Seminar Nasional Pengembangan Teknologi Pertanian Politeknik Negeri Lampung halaman 409-418.Balai Pengkajian Teknologi Pertanian Sumatera Utara Jl. Jend. Besar A.H. Nasution No. 1 B Medan 20143 Telp. (061) 787071

Purwiyatno H., 2013. Peranan Industri Untuk Penguatan Ketehanan Pangan Mandiri dan Berdaulat.Simposium Pangan Nasional Indofood.

Regina H.Y. Fu, Hidehiko K and Makoto M, 2011.Research on Yam Production, Marketing and Consumption of Nupe Farmers of Niger State, Central Nigeria. African Journal Of Agricultura Research Vol. 6 (23) pp 5301-5313.

Sahusilawane A.M, Kembauw E., Matulessy F. 2011. Pelestarian Plasma Nutfah Tanaman Pangan Secara Tradisionil Dalam Menjaga Ketahanan Pangan di Pulau Kisar Kabupaten Maluku Barat Daya Provinsi Maluku. Prosiding Seminar Nasional.Pengembanagan Pulau-Pulau Kecil. Jurusan Budidaya Pertanian Fakultas Pertanian Universitas Pattimura, Ambon.

Tobih, F.O, Okonmoi L.U., Omoloye, AA, 2011. Assesment of Yield Potensials and Damage of Yams in Uncontroled Upland Yam Monocrop System with Varying Planting Dates in Oshimili Area of Delta State, Nigeria. International Journal Of Agriscience Vol. I(3) PP 178-184.

Wuryantoro, 2016. Explorasi Plasma Nutfah Dan Pengembangan Uwi Sebagai Upaya Menunjang Program Diversifikasi Pangan Non Beras (Eksplorasi dan Identifikasi Tanaman Uwi di Eks Karesidenan Madiun). Laporan Penelitian. Fakultas Pertanian Universitas Merdeka Madiun.

Wuryantoro, 2018. Eksplorasi Plasma Nutfah Dan Pengembangan Uwi Sebagai Upaya Menunjang Program Diversifikasi Pangan Non Beras (Kajian Pembuatan Beras Fungsional berbasis Uwi). Laporan Penelitian tahun ke III. Fakultas Pertanian Universitas Merdeka Madiun

Yalindua, A., 2014. Potensi Genetik Klon Tanaman Uwi (Dioscorea alata L.) asal Banggai Kepulauan Sebagai Sumber Pangan Dalam Menunjang Ketahanan Nasional .http://repository.ipb.ic.id. IPB Bogor.Unduh 15 De sember 2018. 